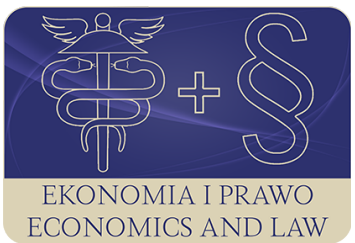

EKONOMIA I PRAWO. ECONOMICS AND LAW

Volume 16, Issue 1, March 2017

p-ISSN 1898-2255, e-ISSN 2392-1625

www.economicsandlaw.pl

EKONOMIA I PRAWO
ECONOMICS AND LAW

ORIGINAL ARTICLE

received 31.01.2017; revised 30.03.2017; accepted 31.03.2017

Citation: Kilanowski, M. (2017). Deep capture: the hidden role of rationalizations, psychology,

and corporate law. Ekonomia i Prawo. Ecomomics and Law, 16(1): 47-57.

doi:10.12775/EiP.2017.004.

\title{
Deep capture: the hidden role of rationalizations, psychology, and corporate law
}

\author{
MARCIN KILANOWSKI \\ Nicolaus Copernicus University, Faculty of Law and Administration, Department of Theory of Law \\ and State, ul. Władysława Bojarskiego 3, 87-100 Toruń, Poland \\ \markil@umk.pl
}

\begin{abstract}
Motivation: The current legal regulations in United States of America and corporate governance stands in the name of such values as freedom and profit. Unfortunately, as presented in the article it is only freedom and profit for corporations.

Aim: The primary purpose of the article is to present what role is played by rationalizations and dispositions in the process of law formation and interpretations on the basis of examples from the corporate law of United States of America. Such rationalizations and our particular dispositions allow corporations to function without much control.

Results: The starting point of the article concerns the environmental disaster that happened at the Deepwater Horizon platform in the Gulf of Mexico in 2010, and was caused by the actions of British Petroleum, a company basing its code of conduct on values such as freedom and profit. Such values understood in one particular way, which help to profit the corporations such as British Petroleum, are the basis for rationalizations and dispositions supporting particular corporate decisions. What is more corporate law legitimizes and supports such rationalizations and strengthens mentioned dispositions by fallowing and reproducing them in court decisions.
\end{abstract}

Keywords: rationalizations; psychology; dispositions; corporate governance; freedom; profit JEL: Z13 


\section{Introduction}

We all care about the environment. While we segregate trash, politicians win Nobel Peace Prizes for green policies, and big businesses - in this case, BP constantly reassures us that they are environmentally conscious and that they create 'responsible operations at every BP operation'" However, this would be a too simplistic description. Unfortunately, caring for the environment has not been BP's priority for years, its peak being perhaps 2010, when we witnessed the oil spill in the Gulf of Mexico. During all the years of the company's operations, there have been many such incidents on their drilling fields, and the environmental concerns raised by the employees changed little in the company's conduct. And all that we happen to know about the incidents is based on articles and independent investigations, their contents being more than alarming; apparently, on BP's premises, the fact that rusty pipelines, tanks with cracks, and old safety cups were constantly in use was nothing out of the ordinary ${ }^{2}$. Why did BP not react?

What we have found out is that those who raised these concerns, like Mr. Sneed, who was among the authors of critical reports, were questioned by the company, 'scolded by supervisors', and threatened with dismissal. The company created reports that proved $99 \%$ compliance with safety regulations when, in fact, there was $80 \%$ noncompliance. But, apparently, keeping up appearances was most important. The company still pledged good intentions and repeated slogans about responsibility for the environment. And even after the BP Deepwater Horizon oil spill, it was named 'runner-up for Openness and Honesty's. How was that possible? Mostly due to the drive for profit: profit that, as corporate law preached, justifies corporate actions and should be the only concern of corporations (Freedman, 1962, p. 133). And those in charge of corporations, as the corporate law school book says, should maximize the profit. Following this line of argument, it is up to corporations to decide which course of action is appropriate: it is not to be decided by, for instance, the courts, which do not have ample knowledge, as was stated in the case Shlensky v. Wrigley $(1968)^{4}$.

${ }^{1}$ Since 2007 BP has worked to implement an operating safety system to create 'responsible operations at every BP operation' as said by T. Odone, a company spokesman (Lustgarten \& Knutson, 2010).

${ }^{2}$ Lustgarten \& Knutson (2010) say: 'A 2001 report noted that BP had neglected key equipment needed for an emergency shutdown, including safety shutoff valves and gas and fire detectors similar to those that could have helped prevent the fire and explosion on the Deepwater Horizon rig in the gulf'.

3 Sverjensky (2010) says: 'even as recently as May 2010, determined long before the Deepwater rig exploded, BP was named runner-up for the 'Openness and Honesty' reporting category at the Corporate Register's 2010 CR Reporting Awards’.

${ }^{4}$ Shlensky v. Wrigley (1968) is a case in which the Court accepted the discretion of the board to determine how to balance the interests of stakeholders. It represents a shift away from the idea that corporations should only pursue shareholder value. 


\section{Rationalizations, dispositions, and blame}

Most of the time, corporate law is conceived of in terms of protecting shareholders. Corporate lawyers, CEOs, and board directors - like those of BP constantly try to reassure us that this is the only constituency they are obliged to serve. But yet another perspective is clear here, and this is a perspective broadly discussed in academia and much present behind the majority of business transactions. The issue at stake is what to do with legal regulations that still constrain us from realizing any business idea that comes to mind. In accordance with such a perspective, no one cares about the shareholders here: it is all about profit, and the case Kann v. American Express clearly shows whose profit it is 5 . What is at stake most of the time, under the cover of protecting shareholders, is the profit of those running the companies. However, apart for generating profit as such, corporations also produce the rationalization according to which the drive for profit is good, because it is done for the benefit of shareholders, which in actual fact is not necessarily the case.

One might say the story of protecting shareholders is similar to the story of the need for unconstrained individual activity. Both were often used as smoke screens - rationalizations - backed with reference to values such as profit and freedom. And reference to both profit and freedom often appeared and still appears together, as in the case of corporate law with, for example, its duty of care test, where the 'reasonableness' of the business decision is measured in the light of one's freedom to act and the goal he or she should have in mind, which is maximizing the profit ${ }^{6}$. Reference to profit and freedom has also helped construct smoke screens from everything that seemed incongruous to the picture, the one right worldview. Our Western culture, imbued with rationalistic philosophy, is abundant in stories of various rationalizations being generated, helping to justify the oppression of infidels, heretics, slaves, criminals, women, the unemployed or the homeless ${ }^{7}$. For centuries, we have heard that 'they were

${ }^{5}$ Kamin v. American Express Company (1976) is a case in which H. Kamin and a minority shareholder filed a shareholder derivative suit against American Express and their officers. For the court, the suit was only based on a disagreement with the company' business decisions. The court held that issues of policy and business management were better left to the judgement of corporate management.

${ }^{6}$ In the United States corporation and business association law (Delaware law and Revised Model Business Corporation Act), the duty of care is part of the fiduciary duty of directors toward the corporation. The director is obliged to act in accordance with good business judgment and to use ordinary care and prudence when taking business decisions - the care an ordinary person would use under similar circumstances. Other aspects of fiduciary duty are duty of loyalty and duty of good faith. Directors' decisions are typically protected under the business judgment rule, so long as they will not breach the duties or the decision will not lead to a loss. If such a breach occurs, the director will not be protected under the business judgment rule and he or she will be required to show the entire fairness of the transaction.

7 Not only do they produce rational arguments, but also rationalizations, and these are two quite different things. 
born to be like that' - naturally undeveloped, insane, or just lazy — and that they have deserved their place in society. The worst part is that those that live by these rationalizations are 'good, ordinary people' responding to market stimuli, an interpretation of the Bible, made up 'scientific data' or, as M. Weber has pointed out, the Protestant concept of success, according to which he who works will be rewarded ${ }^{8}$. This is why $\mathrm{H}$. Arendt talks about 'the banality of evil', which does not just come and go, but approaches slowly and is reproduced in the course of various actions. And this is what social psychology points to as well.

According to social psychology, reproduction appears thanks to the interaction between situations of which we are a part and our dispositions of which we are not conscious ${ }^{9}$. Sometimes, a little rationalization is enough to exploit the disposition of a teacher or a mechanic to continue adminstering electric shocks, as in the Milgram experiment ${ }^{10}$. This has been the power of all the regimes of the 20th century: to rationalize inequality, i.e. that is why some are at the bottom, while others are on the top, and to use people's dispositions. But ideologies have not come to an end. The drive for profit, in the name of the wealth of shareholders and no matter at what cost, is greater than ever before ${ }^{11}$. Our times are dominated by the ideology of wealth maximization. But, in fact, it produces wealth only for some, and rationalization for everybody.

8 Berlin (1958, p. 58) points to 'good ordinary people' that are responsible for the slaughter of individuals, and the simple ideas they believed in. As an example of "madeup scientific data' driven by politics and not by serious scientific inquiry one might consider mass sterilization programs in Nazi Germany. They also supported euthanasia ("mercy killings') as a program implemented to kill German infants and children regarded as a burden on national resources, and later applied to persons who were 'unproductive'. Between 1939-1945 a total of 200,000 people were killed with the support of pediatricians, psychiatrists, family doctors and nurses, with a body of 'scientific' literature supporting such actions. For more on the subject see e.g. Fridlander (1995), Kevels (1998), Michalczyk (1994). Regarding the analysis of the Protestant conception of success see: Weber (2010).

9 For more on the expression and concept of 'the banality of evil', see Arendt (2003). In the book, Arendt explains that Eichmann was neither a fanatic nor a madman, but an average human. He was following orders and was more concerned with his own interests and personal advancement than by ideology. She does not question that he was anti-Semite, although that was less important than his 'stupidity'.

10 The Milgram experiment was conducted by S. Milgram, a professor of psychology from Yale University. In that experiment Milgram tested obedience to an authority figure who asked them to act against their personal conscience. Milgram first described his research in an article in the Journal of Abnormal and Social Psychology and later in 1974 in his book Obedience to Authority: An Experimental View (Milgram, 1974).

${ }^{11}$ More on that see Chen \& Hanson (2004, pp. 1-148). 


\section{The way to deal with the issue}

We are 'good people' that do not see that we are doing wrong by pressing one button of Milgram's electric shock box after another. What guides us is our disposition to rationalize and comply, to follow easy explanations of causal relations and simplistic understanding of various situations, which are pressing on us in a direction we are often not aware of. If we come to see that the outcome of our actions is something that we did not quite expect, we blame the situation, not recognizing that it would not have had such a significant effect if we had seen our own role in the whole process - in allowing the dispositions to control us, in creating and following various rationalizations. As soon as we start rationalizing - building simplistic and coherent explanations and taking things for granted - we are less and less able to see the other forces that guide us: our implicit motives, attributions, presumptions and images of the world that have replaced the real world of other human beings. The goal here will be to show on the basis of $\mathrm{BP}$ case how this forces are playing a role in corporate governance and how corporate law legitimises such governance to the point that it is hard to see a way out. The reference to legal cases will allow to show how serious is the situation and how protected is the drive for profit and almost unconstrained corporate freedom based on the concept of business judgement rule.

\section{Fighting for freedom}

In the light of that it can be said - coming back to the case at stake - that corporations' leaders, managers, and directors are not bad people; they are 'good people' too. They often say, as BP does now, that it was the rig's owner and operator Transocean that was to blame, or it was the fault of the employees 'not following BP's own procedure', taking 'shortcuts and risks'12. If these employees had just worked better, or if they had just paid more attention, the oil spill would not have happened. CEOs rationalize and blame the situation, not seeing that it is their own disposition that blinds them from seeing their own role in the way catastrophic events unfold. And this is caused by the drive for profit and 'meeting performance targets' to present 'shiny statistics' — sometimes by making them up - to keep up with competitors, because this is what the 'free market requires' and what corporate law supports by regulations ${ }^{13}$.

12 Chazman et al. (2010) mention that BP has turned a page on safety. They say that BP’s spokesman Andrew Gowers has said ‘BP's absolute number one priority is safe and reliable operations'. However, some think that the cost drive affects safety. As Ross Macfarlane, a former BP health and safety manager on rigs in Australia, who was laid off in 2008 says, workers had 'high incentive to find shortcuts and take risks'. He added that 'you only ever got questioned about why you couldn't spend less - never more'. Of course, BP vigorously denies putting savings ahead of safety.

13 In Sverjensky (2010) we can read: 'Placement on awards and rankings allows companies to keep up with their competitors and produce annual reports with shiny statistics and nice pictures. But they don't bring us nearly as close as needed to building the low-car- 
What is crucial in this context is the free market, as well as individual freedom within its borders. They cannot be questioned and must be protected from critics, the enemy necessary to combat. There is a long tradition that corporations follow in such cases. The way was prepared long ago, and can be exemplified by Louis Powell's (the future Supreme Court Judge) 'Confidential Memorandum' calling to 'Fight Back' when the way corporations function is questioned. According to his report, everyone is to play a role in this battle: the American Chamber of Commerce, lobbyists, lawyers, academics, textbooks, media, and politicians. As corporations were told, 'there should be no hesitation in attacking the Naders, the Marcuses and others who openly seek destruction of the system... nor should there be reluctance to penalize politically those who oppose it ${ }^{14}$. All the resources are supposed to be used to combat and rationalize by telling the story of free America, in which 'the contraction and denial of economic freedom is followed inevitably by governmental restrictions on other cherished rights' (Powell, 1971). There was just one perspective that was supposed to survive, only one that people should believe. This was that profit is what we should cherish and that consumption is what we should focus on, without being aware of the consequences it has on our lives and the environment. Furthermore, what was also always at stake was our individual freedom.

As we can observe on the basis of Powell's example, the goal of corporations was to fight criticism coming from society, against the attempts of the government to regulate business, against the threat of losing profits. All of that in the name of preserving the free market and individual freedom of choice, of one right vision of the economy, of human activity and what counts as a good life. And it could be said that the goal was achieved with the victory of the free market over the centrally planned one. But was it really a victory? Is corporate capitalism different than centralized communist economy? If we go down the Hayek (1994) list of what leads to serfdom, we will see that the criteria are also fulfilled in the way the corporate world functions, thanks to the present legal rules (in the USA this is primarily the Delaware law). In communism, everything belonged to everybody, but was governed in a centralized way. Similarly, today's corporations, which belong to every shareholder, are governed in a centralized manner, where the majority shareholder that can have a say in the functioning of the corporation, although most of the time it is the directors' duty to balance the different interests of shareholders ${ }^{15}$. Of course, the argument goes that there

bon, sustainable economies of the future' Supra note 3 .

14 The author of Powell's Memo is L. Powell. A corporate lawyer and member of the boards of 11 corporations, Powell wrote a confidential memo in 1971 to his friend E. Sydnor, Jr., the Director of the U.S. Chamber of Commerce. Not too long afterwards, he was nominated by President Nixon to the U.S. Supreme Court (Freudenberg, 2014, p. 71).

15 Since Shlensky v. Wrigley (1968) and AP Smith Manufacturing Company v. Barlow (1953), the balancing of stakeholder interests has been left to a director's business judgment. The ruling of this case suggest that Dodge v. Ford Motor Company (1919) no longer represents the law in most states. 
is a difference, because being a shareholder is a voluntary activity, and everyone can still sell their assets. But can we really leave the corporate world? We will always feel the consequences that the BP profit maximization philosophy brought upon us - the polluted environment - whether we are shareholders or not. The question is: is this the 'free market' and the free world which we wanted?

\section{The disposition}

The present form of the market is praised, because 'an organization's internal governance affects its performance' and this leads to 'success' (Allan \& Kraakman, 2003, p. 3). But now it is obvious whose success this is. Milton Friedman's analysis, according to which the free market is governed by an 'invisible hand' which will create more wealth for everybody has not materialized ${ }^{16}$. The divisions in economic standing are growing rapidly, and ecological disasters happen more and more often. But we still follow what he said, and it does not matter which political leaning we are inclined towards. Friedman is praised by those previously in government (Bush) and by those at present (Summers). He is also praised in academic works, for "facilitating individual efforts to create wealth is wise public policy', even though their authors admit that wealth 'is not always deployed to advance total human welfare' (Allan \& Kraakman, 2003, p. 3 ), though this is not the business of corporations.

And where are we now? We behave as if we were taking part in Milgram's experiment and we 'shock' people at home and abroad, ourselves, our children, and future generations by acting harmfully without thinking about the consequences of our actions and the following rationalizations about the 'drive for profit' and unconstrained individual freedom. We ruin other people's personal and social lives, destroy possible relations of trust and friendship, and devastate families, when, in the name of profit, they are evicted from their homes because they are not able to pay the mortgage $\mathrm{e}^{17}$. We also ruin both their and our own health by allowing environmental pollution, upheld by the activities of corporations such as BP. Of course, the standard answer would be that people have a choice, that they are free. Those people could just work harder and their life were different. They could pay more attention at work and secure their position, like Mrs. Pritchard in the case Francis v. United Jersey Bank (1981). They are the ones to blame if something goes wrong, just as they are responsible for their own lives. But by giving such an answer, we will continue to 'shock' them as

${ }^{16}$ Friedman defends profit-making against critics and he defends Adam Smith's idea of 'the invisible hand of the market'. However, the difference is that he only applies it to corporations and rejects any moral responsibility, unlike Smith, on the part of corporations.

17 Such a situation took place in United States during the Great Recession that began with Subprime Mortgage Crisis, which resulted in homes being worth less than the mortgage taken out on them. The resulting significant number of foreclosures led to a slump in consumer spending and an erosion of the financial strength of banking institutions and other parts of the economy (Baily \& Elliott, 2009). 
well as ourselves, because what we do to others sooner or later has consequences for us.

One cannot be satisfied with this answer when applying critical thinking. The answer to the question why these people were not able to direct their lives differently will point to their disposition. They blamed the situation instead of blaming themselves or others who created the conditions for a future crisis, exploitation or harm done to other people. And we sometimes start realizing the processes of which we are a part, and which we shape by our action or inaction. However, most of the time it is after and not before that the harm was done. Can we change that? We can propose reforms in the legal system. In the case of the oil drilling industry, we can propose excessive liability caps for energy exploration activities, increase the availability of non-economic damages, and levy excessive new energy taxes, but the industry itself is resistant to all of these propositions. As we can read in the U.S. Chamber of Commerce Letter, 'Congress should resist the rush to act on legislation' because that will be too much of a burden on corporations and their profits. Companies would 'be unable to afford insurance to cover the liability risk'. Moreover, awarding damages is 'entirely subjective', and courts would not be able to evaluate cases in the correct way (Josten, 2010). In short, the Chamber believes that the best thing is to leave corporations alone. By that, it follows what Powell has taught: to oppose any governmental restrictions and regulations, because what matters is maximizing profit and unconstrained freedom to act.

It is not only the Chamber of Commerce that has reacted to the attempts to regulate. In Louisiana alone there were '72 oil and gas lobbyists, 25 chemical industry lobbyists and 43 lobbyists for the chamber of commerce and business groups' (Harkinson, 2010). All of them worked through seven environmental lobbyists, two of whom also lobbied for Chevron. This is Powell's strategy in action. Moreover, regulations are also opposed by 'political contributions'. Donations often run into the millions and keep politicians' critical thinking switched $\mathrm{off}^{18}$. Even Nature Conservancy, a non-profit group, accepted millions in cash and was on the BP International Leadership Council. Conservation International also received millions (Stephens, 2010).

We can say that such contributions are not appropriate and CEOs will admit that too, when faced with the data. As in the case of BP, they will point to the 2002 'policy to stop making corporate donations anywhere in the world' that they have implemented after years of making donations. But it did not stop after 2002 (Leonning, 2010). Who was responsible for that? Again, it is an inadequately trained employee who was not prepared for the job that is to blame. However, corporations and their directors are acting appropriately, and if someone in the corporation acts negligently, the corporation should not be the one to blame. They would have to 'neglect cavalierly' to be held responsible according to the case Graham v. Allis-Chalmers Manufacturing Company

18 A more in-depth presentation of the issue of financing political parties and an approach to change this can be found in Lessig (2012). 
$(1963)^{19}$. They would have to ignore 'either will fully or through inattention obvious danger signs of employee wrongdoing', but they will certainly say that they did not know. Ultimately, we can speak about the 'deep capture' of attempts to regulate and the 'deep capture' of knowledge of those independent NGOs that cooperated with BP and did not prevent the oil spill from happening again. Striving for profit was preserved through various acts and rationalizations. Individual choice free of governmental encroachment was protected. The blame was passed to the guilty ones as before, to the employees, to the situation or the lack of knowledge.

\section{Conclusion}

Executives continue to prosper. After all, the BP executives were not held accountable for the oil spills in the Gulf of Mexico, California and Texas, and some were promoted despite these accidents. But the government is trying. The National Oil Commission has pointed out systematic failures across the whole industry. Senator B. Graham said that after Deepwater Horizon there is a chance to overcome the 'ideological preference for less government' (Sheppar, 2011). He was optimistic about the likelihood of proposals actually going somewhere in a Republican-controlled House. His full statement was: 'I believe that this issue and the searing impact that Deepwater Horizon has had on the conscience of America is such that it will override an ideological preference for less government, less government intrusion' (Sheppar, 2011). But even if the government succeeds in one case, the problem prevails. The problem of the reproduction of a 'culture of coziness', the problem of agencies such as the Minerals Management Services being 'friendly with those it regulated', will still remain (Naylor, 2011). Such problems can easily appear in different sectors. The problem also continues due to legal regulations that protect corporations from control and thanks to the rationalisations which justify that unconstrained freedom and profit are the most important values in corporate governance and in our life.

\section{References}

Allan, W.T., \& Kraakman, R. (2003). Comentaries and Cases on the Law of Business Organization. New York: Aspen Publishers.

AP Smith Manufacturing Company v. Barlow, 98 A.2d 581 (1953).

Arendt, H. (2003). Eichmann in Jerusalem. A Report on the Banality of Evil. London: Penguin Classics.

Baily, M.N., \& Elliott D.J. (2009). The US Financial and Economic Crisis: Where Does It Stand and Where Do We Go From Here? Retrieved 26.07.2016 from http://www.brookings.edu.

19 This case established the Graham Standards, which basically impose a duty of inquiry on the directors only when there are obvious signs of employee wrongdoing. 
Berlin, I. (1958). Two Concepts of Liberty. In I. Berlin (Ed.), Four Essays on Liberty. Oxford: Oxford University Press.

Chazman, G., Faucon, B., \& Casselman, B. (2010). As CEO Hayward Remade BP, Safety, Cost Drives Clashed. Wall Street Journal, 20.06.2010. Retrieved 26.07.2016 from http://www.wsj.com.

Chen, R., \& Hanson, J. (2004). The Illusion of Law: The Legitimating Schemas of Modern Policy and Corporate Law. Michigan Law Review, 103(1). doi:10.2307/4141976.

Dodge v. Ford Motor Company, 170 N.W. 668 (1919).

Francis v. United Jersey Bank, 87 N.J. 15, 432 A.2d 814 (1981).

Freedman, M. (1962). Capitalism and Freedom. Chicago: University of Chicago Press.

Freudenberg, N. (2014). Lethal But Legal: Corporations, Consumption, and Protecting Public Health. Oxford: Oxford University Press.

Fridlander, H. (1995). The Origins of Nazi Genocide: From Euthanasia to the Final Solutions. Chapel Hill: The University of Northern Carolina Press.

Graham v. Allis-Chalmers Manufacturing Company, 41 Del. Ch. 78, 188 A.2d 125 (1963).

Harkinson, J. (2010). BP: Beyond Prosecution. Mother Jones, 30.06.2010. Retrieved 26.07.2016 from http://www.motherjones.com.

Hayek von, F. (1994). Road to Serfdom. Chicago: University of Chicago Press.

Josten, R.B. (2010). Letter Regarding Legislation Related to the Gulf of Mexico Oil Spill to the members of the United States Congress. Retrieved 26.07.2016 from https://www.uschamber.com.

Kamin v. American Express Company, 383 N.Y.S.2d 807 (1976).

Kevels, D.J. (1998). In the Name of Eugenics: Genetics and the Uses of Human Heredity. Cambridge: Harvard University Press.

Leonning, C.D. (2010). Despite BP Corporate Code. Firm Has Made Political Contributions. Washington Post, 30.07.2010. Retrieved 26.07.2016 from http://www.washingtonpost.com.

Lessig, L. (2012). Republic, Lost: How Money Corrupts Congress and a Plan to Stop It. New York: Grand Central Publishing.

Lustgarten, A., \& Knutson, R. (2010). Reports at BP over Years Find History of Problems. Washington Post, 08.06.2010. Retrieved 26.07.2016 from http://www.washingtonpost.com.

Michalczyk, J. (Ed.). (1994). Medicine, Ethics, and the Third Reich: Historical and Contemporary Issues. Kansas City: Sheed \& Ward.

Milgram, S. (1974). Obedience to Authority: An Experimental View. New York: Harper and Raw.

Naylor, B. (2011). Drilling Oversight Agency Faces Troubling Obstacles. Retrieved 26.07.2016 from http://www.npr.org.

Powell, Jr. (1971). Confidential Memorandum: Attack on American Free Enterprise System. Retrieved 26.07.2016 from http://law2.wlu.edu. 
Sheppar, K. (2011). Did We Learn Anything From BP Oil Spill? Mother Jones, 12.01.2011. Retrieved 26.07.2016 from http://www.motherjones.com.

Shlensky v. Wrigley, 95 Ill. App. 2d 173, 237 N.E.2d 776 (1968).

Stephens, J. (2010). Nature Conservacy Faces Potential Backlash from Ties with BP. Washington Post, 24.05.2010. Retrieved 26.07.2016 from http:// www.washingtonpost.com.

Sverjensky, N. (2010). Beyond Petroleum: Why the CSR Community Collaborated in Creating the BP Oil Disaster. Retrieved 26.07.2016 from http://www.ethicalcorp.com.

Weber M. (2010). The Protestant Ethics and the Spirit of Capitalism. New YorkLondon: Routledge.

\section{Acknowledgements}

Author contributions: author have given approval to the final version of the article. 
